\title{
Abiotic Factors That Affect The Distribution of Aquatic Macrophytes In Shallow Lakes Located In Sibley County, Minnesota, USA: A Spatial Modeling Approach
}

\section{Samuel Schmid}

Minnesota State University Mankato

Ryan Wersal ( $\nabla$ ryan.wersal@mnsu.edu )

Minnesota State University Mankato

Jonathan Fleming

Samford University

\section{Research Article}

Keywords: submersed aquatic vegetation, sediment texture, sediment organic matter, generalized linear regression, water depth, distance from shore

Posted Date: July 20th, 2021

DOl: https://doi.org/10.21203/rs.3.rs-667792/v1

License: (c) (1) This work is licensed under a Creative Commons Attribution 4.0 International License.

Read Full License 


\section{Abstract}

Macrophytes are an integral component of lake communities, therefore understanding the factors that affect macrophyte community structure is important for conservation and management of lakes. In Sibley County, Minnesota, USA, five lakes were surveyed using the point-intercept method. At each point the presence of macrophytes were recorded, water depth was measured, and a sediment sample was collected. Sediment samples were quantified by determining soil particle size and percent organic matter. The richness of macrophytes in all lakes were modeled via generalized linear regression with six explanatory variables: water depth, distance from shore, percent sand, percent silt, percent clay, and percent sediment organic matter. If model residuals were spatially autocorrelated, then a geographically weighted regression was used. Water depth and distance from shore were negatively related to mean species richness, and silt was either negatively or positively related to species richness depending on the lake and macrophytes present. All species richness models had $p$ seudo- $\mathrm{R}^{2}$ values between 0.25 and 0.40. Curlyleaf pondweed (Potamogeton crispus) was related to with water depth, percent silt, and percent sediment organic matter during early season surveys.

\section{Introduction}

Aquatic macrophytes are important primary producers and ecosystem engineers in freshwater systems (Koch, 2001). The majority of all aquatic vegetative growth occurs in the littoral zone; the transitional space between the profundal zone and the terrestrial landscape (Madsen et al., 2008). Aquatic macrophyte communities influence the structure and function of aquatic systems in many ways. Aquatic macrophytes provide food and habitat for waterfowl, fish, and macroinvertebrates (Waters \& Giovanni, 2002; Wersal et al., 2005; Dibble \& Pelicice, 2010). In addition to supporting animal communities, aquatic macrophytes inhibit the growth of phytoplankton allopathically, and provide habitat for important filter feeders that graze on phytoplankton; which can mitigate the frequency and intensity of algal blooms (Scheffer, 1999; Körner \& Nicklisch, 2002; Takamura et al., 2003; Bakker et al., 2010). Aquatic vegetation can also improve water quality by promoting the settling of suspended sediment and inhibiting the resuspension of settled sediment by reducing wave action in the water column (Barko \& Smart, 1986; James et al., 2004). The benefits of a diverse aquatic plant community affirm its value as an integral constituent of the freshwater lake system. Understanding the factors that affect the composition of the aquatic macrophyte community is important for managing aquatic systems, and preserving their structure and function.

Light availability is considered the principal limiting factor for the growth of aquatic macrophytes (Chambers \& Kaiff, 1985; Barko et al., 1986; Lacoul \& Freedman, 2006). Light is a rate limiting factor for the primary productivity of plants, and in aquatic systems, light is often limited by the attenuation of light by the water column (Lacoul \& Freedman, 2006; Bornette \& Puijalon, 2011). Light regime is the primary driver for the niche partitioning of aquatic macrophytes throughout the littoral zones of lakes (Barko et al., 1986). The typical structure of the littoral zone consists of angiosperms at shallow depths and bryophytes and charophytes at deeper depths (Chambers \& Kaiff, 1985; Blindow, 1992). This zonation is 
primarily driven by the availability of light and the adaptations of plants to those light conditions. Light availability is also a strong determinant of macrophyte growth form. Lakes with very low light availability are often dominated by floating leaf and free-floating macrophytes that are adapted to grow leaves at the surface, where light is not limited (Lacoul \& Freedman, 2006). Conversely, submersed macrophytes are generally more abundant in lakes where there is more light available in the water column (Lacoul \& Freedman, 2006).

Water depth is also an important factor that affects distribution of macrophytes in lakes. Many lakes have a maximum depth of macrophyte colonization that is shallower than the maximum depth of the lake (Chambers \& Kaiff, 1985; Rooney \& Kalff, 2000). When water depths in the middle of the lake exceed the maximum depth of colonization, a profundal zone is present with the littoral zone found around the margin. The profundal zone is typical in deep lakes; however, in shallow lakes it may be absent entirely. Water depth is often considered an inhibiter of macrophyte growth because the water column attenuates more light as depth increases. This also explains why macrophytes at lower depths are often better adapted to lower light conditions than macrophytes at shallower depths. Overall, water depth has been found to have a negative relationship between the density and abundance of aquatic macrophytes (Barko et al., 1986; Cheruvelil \& Soranno, 2008).

One of the major factors that limits the growth of aquatic macrophytes is water turbidity. Light availability in aquatic systems is primarily a function of turbidity and water depth (Barko et al., 1986; Lacoul \& Freedman, 2006; Bornette \& Puijalon, 2011). Turbidity in a lake system is mostly caused by suspension and resuspension of fine textured sediment (James et al., 2004). Suspended sediment can increase light attenuation and nutrients in the water column which reduces light availability and can promote algal blooms, thus inhibiting the growth of submersed macrophytes (James et al., 2004; Zhu et al., 2015). However, aquatic macrophytes can affect the turbidity of lake systems. Many studies have found that the presence of aquatic macrophytes reduces wave action and, consequently, reduces suspension and resuspension of fine sediments that contribute to turbidity (Barko et al., 1991; Madsen et al., 2001; Wu \& Hua, 2014). The relationship between turbidity and aquatic macrophytes is complex, but abundant evidence implicates turbidity as a major limiting factor for plant growth through limiting light availability

Another important factor that affects the abundance and distribution of aquatic macrophytes is the fetch, the distance wind can travel unimpeded. In shallow lakes, one of the primary determinants of wave action is fetch (Andersson, 2001; Lacoul \& Freedman, 2006). Depending on the intensity of the wave energy, the effects of wave action may be positive or negative. Macrophytes may respond to high wave action by changing their morphology, and moderate wave action may increase nutrient availability for the macrophyte community (Madsen et al., 2001; Lacoul \& Freedman, 2006; Bornette \& Puijalon, 2011). Wave action may also contribute to suspension and resuspension of fine textured sediment that may affect community structure in various ways (Madsen et al., 2001; James et al., 2004). 
A lake's sediment is highly influential on the macrophyte community, and interactions between sediment and macrophyte communities are highly complex (Barko \& Smart, 1986; Barko et al., 1991). Fine sediments can contribute to turbidity, but sediment texture affects macrophytes in many other ways. For instance, Stuckenia pectinata (L.) Böerner (sago pondweed) has shown a proclivity for growth in sediments with abundant silt (Madsen et al., 1996; Koch, 2001; Case \& Madsen, 2004). In Swan Lake and Middle Lake, Nicollet County, MN, USA, clayey sediment was positively related the presence of sago pondweed, but negatively related to the presence of Vallisneria americana Michx. (American eelgrass) (Madsen et al., 2006). Finer sediment like silts and clays can be both beneficial and detrimental to macrophytes, and effects are species specific. In finer sediments, macrophytes generally encounter a trade-off between nutrients and bulk density (Gerbersdorf et al., 2007). Finer sediment particles often have a higher activity, which improves cation exchange capacity (CEC), elevating nutrient availability. However, reduced porosity of finer sediments can inhibit root growth as bulk density is greater and generally results in more hypoxic sediments (Koch, 2001; Gerbersdorf et al., 2007). Evidence from numerous studies suggests that the interface between macrophytes and sediment is a major factor that affects macrophyte community structure.

Factors that affect the structure of the macrophyte community are highly influential on the structure and function of lake systems. Lakes of Minnesota are very diverse and this is largely due to landscape diversity across the state. State-wide, shallow lakes (max depth $\leq 4.5$ ) are more common than deep lakes (max depth $>4.5 \mathrm{~m}$ ) (Radomski \& Perleberg, 2012). In Minnesota, regions with deeper and more oligothrophic lakes, have lakes with much greater macrophyte richness than regions with shallow, eutrophic lakes (Radomski \& Perleberg, 2012). Much of southern Minnesota is situated in the Prairie Pothole Region, where lakes are much shallower and more species poor than most other regions of Minnesota (Guntenspergen et al., 2002; Radomski \& Perleberg, 2012). The ecology and management of shallow lakes is fundamentally different from typical lakes as they are generally warmer, more turbid, and more productive than deep lakes (Scheffer, 2004). Managing lakes in southern Minnesota requires an understanding of how certain physical and geographic factors affect the aquatic macrophyte community. The purpose of this study is to quantify the relationships between mean species richness, lake sediment, and geographic factors in five major lakes in Sibley County, MN, USA.

\section{Materials And Methods}

\section{Study site}

The current study took place in Sibley County, MN which is located in the Prairie Pothole Region of North America (Guntenspergen et al., 2002) (Fig. 1). Cultivated land makes up 79\% of Sibley County's total land area (Sibley County, 2018). Dominant soil series include Lester soil series and Canisteo soil series, both of which are fine loams with relatively high CEC (National Resource Conservation Service, 1997). For this study, five natural, shallow lakes were surveyed: High Island Lake, Titlow Lake, Schilling Lake, Silver Lake, and Clear Lake (table 1, Fig. 1). These lakes are warm, eutrophic to hypereutrophic systems that are characterized by high productivity and turbidity throughout the growing season. Recreation is the primary 
use of these lakes, which primarily consists of boating, fishing, and duck hunting. Dominant submersed aquatic macrophytes in the study lakes were Ceratophyllum demersum L. (coontail), Potamogeton crispus L. (curlyleaf pondweed), and sago pondweed, with Typha spp. L. (cattails) being the dominant shoreline macrophytes in 2019 (Schmid \& Wersal, 2021).

\section{Lake surveys}

Similar to other studies in southern Minnesota, all five lakes in Sibley Co. were surveyed using pointintercept surveys (Woolf \& Madsen, 2003; Case \& Madsen, 2004; Madsen et al., 2006; Wersal et al., 2006). For all five lakes, survey points were arranged in a $150 \mathrm{~m}$ grid (Fig. 2-6). These point grids were used to conduct macrophyte community and sediment surveys during the early season (May and June) of 2019. During the surveys, these points were navigated to by watercraft under the direction of a GPS enabled ruggedized tablet with a spatial accuracy 1-2 m (Trimble Navigation Limited, Sunnyvale, California, USA). At each point, a plant rake was deployed and allowed to reach the benthos after which it was retrieved. All plants attached to the plant rake were identified and plant species presence was recorded. Sediment cores were also taken at each point by pushing a $5 \mathrm{~cm}$ diameter sediment corer into the benthos between $20 \mathrm{~cm}$ and $30 \mathrm{~cm}$ deep to collect an adequate sediment volume. Additionally, depth at each point was recorded using a sounding rod. All spatial data were recorded electronically using Site Mate software (Farm Works Information Management, Hamilton, Indiana, USA) that recorded geospatial data and allowed for the entry of geospatial attributes in the field, which reduced data entry errors and postprocessing time (Wersal et al., 2010; Cox et al., 2014; Madsen et al., 2015). A pick list of aquatic macrophytes was constructed for these surveys that allowed for the recording of macrophyte species in a database template. Mean species richness was calculated for each lake by averaging the number of unique species at each point. Secchi depth was also recorded during surveys at each lake. Secchi depth was measured near the geographic center of the lake at mid-day during clear weather.

\section{Sediment analyses}

Prior to all sediment analysis, stored sediment cores were homogenized and dried in a forced-air drying oven for $48 \mathrm{hrs}$ at $105^{\circ} \mathrm{C}$. Composition of the fine-grained fraction (particle size) and percent organic matter were both estimated for all oven-dried samples. A minimum of $60 \mathrm{~g}$ of oven-dried sediment per sample was used for both analyses.

Particle size of oven-dried sediment samples was estimated using the Bouyoucos hydrometer method (Bouyoucos, 1962). A $50 \mathrm{~g}$ portion of oven-dried sediment was weighed and the exact weight was recorded $(m)$. To disperse sediment aggregates, samples were pulverized using a combination of a mortar and pestle and a ceramic spur grinder. After pulverization, sediment samples were then combined with $100 \mathrm{~mL}$ of a dispersal agent, which was a solution of $50 \mathrm{~g}$ of sodium hexametaphosphate dissolved in $1 \mathrm{~L}$ of distilled water. The mixture of sediment and dispersal agent was homogenized using a sediment mixer (SA-14, Gilson Company, Inc, Lewis Center, Ohio, USA). The mixture sat for $24 \mathrm{hrs}$ before it was mixed for another $2 \mathrm{~min}$ in the mixer. The mixture was then added to a $1,000 \mathrm{~mL}$ sedimentation cylinder and distilled water was added to bring the final volume to $1,000 \mathrm{~mL}$. A blank cylinder was prepared by 
combining $100 \mathrm{~mL}$ of dispersal agent and $900 \mathrm{~mL}$ of distilled water. Samples in each cylinder were thoroughly mixed prior to the start of each test by capping the cylinder with a bung and inverting it multiple times. A hydrometer reading was taken at 40 s and $2 \mathrm{hrs}$ after start time. Hydrometer readings were taken from blank cylinders after each test reading and the ambient air temperature was recorded. Test readings were then corrected by subtracting the blank reading from them and adding or subtracting by a factor of 0.1 for every degree below or above $20^{\circ} \mathrm{C}$ respectively. The corrected 40 s reading was represented as hydrometer $1\left(H_{1}\right)$ and the corrected $2 \mathrm{hrs}$ reading was represented as hydrometer $2\left(\mathrm{H}_{2}\right)$. Proportion of sand $\left(P_{\text {sand }}\right)$, silt $\left(P_{\text {silt }}\right)$, and clay $\left(P_{\text {clay }}\right)$ in the sediment samples was estimated using the following formulae:

$$
\begin{aligned}
& P_{\text {sand }}=1-\frac{H_{1}}{m} \\
& P_{\text {clay }}=\frac{H_{2}}{m} \\
& P_{\text {silt }}=1-\left(P_{\text {sand }}+P_{\text {silt }}\right)
\end{aligned}
$$

Proportions of sand, silt, and clay, were multiplied by 100 to represent the percent of the sediment for which each constituent accounted.

The SOM of sediment samples were estimated using the loss on ignition (LOI) method (Dean, 1974; Heiri et al., 2001). Of the oven-dried sediment samples, $5 \mathrm{~g}$ was measured and recorded and represented the pre-ignition weight $\left(m_{\text {pre }}\right)$. The samples were placed in crucibles and set in a muffle furnace. The muffle furnace cycled at $550^{\circ} \mathrm{C}$ for $16 \mathrm{hrs}$ and the samples were re-weighed $\left(m_{\text {post }}\right)$. The proportion of SOM $\left(P_{S O M}\right)$ in the samples was calculated using the following formula:

$$
P_{\text {SoM }}=\frac{m_{\text {pre }}-m_{\text {post }}}{m_{\text {pre }}}
$$

The $P_{\text {SOM }}$ was then multiplied by 100 to represent the percent of the sediment that consisted of SOM.

\section{Spatial modeling and statistical analyses}

All geoprocessing and geospatial analyses were conducted using ArcMap and ArcGIS Pro (Environmental Systems Research Institute, Redlands, California, USA). Data from lake surveys consisted of presence and absence of macrophyte species, water depth, and geographic coordinates. Species richness and distance from shore of each point was calculated and added as an attribute. A point's distance from shore was determined by calculating the shortest distance from that point to the edge of the lake polygon. Generalized linear regressions (GLR) were performed on survey data to determine relationships between macrophyte species richness and water depth, distance from shore, percent sand, percent silt, percent clay, and percent SOM within lakes (Fleming et al., 2021). Additionally, relationships between these same independent variables and the presence and absence of both curlyleaf pondweed and sago pondweed in Schilling Lake were analyzed using a GLR. All mean species richness models were 
performed using macrophyte data from the early season surveys. However, Schilling Lake's macrophyte community shifted from curlyleaf pondweed dominated in the early season, to sago pondweed dominated in the late season (Schmid \& Wersal, 2021). To assess this shift the relationships between macrophytes and the explanatory variables in Schilling Lake, GLR's were performed on macrophyte data from late season surveys (August - September) in 2019, using the same explanatory variables. Model performance was determined principally by the corrected Akaike's information criterion (AICC) values, where a lower AICc is considered a stronger model (Fleming et al., 2021). Candidate models with AICc values that were within \pm 2 of each other were considered not significantly different. In cases where the strongest models were not significantly different, the most parsimonious model was considered the strongest model. The strongest model was then considered the best-fit model for the dependent variable. After the best-fit model was determined, a Moran's I test for spatial autocorrelation was conducted on the residuals of that model (Chen, 2016). If the Moran's I test determined the residuals to be non-randomly distributed, then a geographically weighted regression (GWR) was executed using the same variables as the GLR. Neighborhoods for the GWR were produced using the golden search function. Model performance was assessed based on the appropriate pseudo- $R^{2}$ values provided in regression outputs. Statistical significance for all analyses were determined with $a=0.05$.

\section{Results}

Mean species richness at High Island Lake was 0.62. The best-fit model for the species richness in High Island Lake consisted of water depth as the only explanatory variable. The candidate model had a pseudo $\mathrm{R}^{2}$ of 0.281 (table 2 ). Water depth was negatively related to species richness with a slope coefficient of -1.5416 (table 3). Global Moran's I found that the residuals of the candidate model were significantly clumped $(Z=4.498, P<0.001)$ (table 3 ) and so a GWR was performed on the best-fit model. GWR had an improved $p s e u d o R^{2}$ of 0.374 when compared to the global model which had a $p s e u d o R^{2}$ of 0.278 .

Mean species richness at Titlow Lake was 0.16 . There were no significant explanatory variables for species richness in Titlow Lake according to the GLR. GLR with clay as the sole explanatory variable had the highest performance, but the $p s e u d o R^{2}$ value was 0.010 (table 2). According to Moran's $I$, the residuals for this GLR were clumped $(Z=1.837, P=0.066)$ (table 3$)$, However, $G W R$ was unable to find enough variation in species richness across at least one of the neighborhoods, and was therefore unable to execute.

Mean species richness at Schilling Lake was 0.69. Mean species richness for Schilling Lake was negatively related water depth and silt. Pseudo- $\mathrm{R}^{2}$ for this best-fit model was 0.285 (table 2). Slope coefficients for the explanatory variables were -0.8854 and -0.0284 for water depth and silt respectively (table 3). Residuals for this best-fit model were also clumped $(Z=3.708, P<0.001)$ (table 3 ) and so a GWR was performed on these variables. Pseudo $R^{2}$ for the global model with these variable was 0.2679 and the GWR had a pseudo- $R^{2}$ of 0.4169 . Early season frequency of occurrence for sago pondweed and 
curlyleaf pondweed in Schilling Lake was 6.25 and 44.44 respectively. Early season presence and absence of curlyleaf pondweed was modeled with water depth, silt, and SOM as explanatory variables. Pseudo- $\mathrm{R}^{2}$ of the best-fit model was 0.143 (table 4). In the early season both water depth and silt were negatively related to presence and absence of curlyleaf pondweed, with slope coefficients of -1.4582 and - 0.0613 respectively (table 5). Conversely, early season presence and absence of curlyleaf pondweed was positively related to SOM with a slope coefficient of 0.0367 (table 5). Residuals from this model were clumped according the Moran's I $(Z=3.959, P<0.001)$ (table 5). GWR on these variables produced a pseudo $R^{2}$ of 0.341 , which is greater than the global model's $p$ seudo $R^{2}$ of 0.116 . The model on the early season presence and absence of sago pondweed found no significant explanatory variables (table 5). The strongest explanatory variable for the presence/absence of sago pondweed was percent silt, which had a P-value of 0.544 (table 5). Residuals of this model were randomly distributed $(Z=-1.086, P=0.278)$ (table 5). During the late season survey, frequency of occurrence was 63.89 for sago pondweed and 13.89 for curlyleaf pondweed in Schilling Lake. The best-fit model for late season presence and absence of curlyleaf pondweed had a pseudo- $\mathrm{R}^{2}$ of 0.070 and included water depth as the sole explanatory variable (table 6\&7). Water depth was negatively related to curlyleaf pondweed presence during the late season survey, and the residuals for the best-fit model were clumped (table 7). A GWR on the relationship between curlyleaf pondweed late season presence and absence and water depth provided an improved pseudo- $\mathrm{R}^{2}$ of 0.162 over 0.070 from the global model. Late season presence and absence of sago pondweed was explained by water depth and silt according to the best-fit model (table 6\&7). Water depth was negatively related to the late season sago pondweed presence and absence, whereas silt was positively related to sago pondweed presence and absence (table 7). The best-fit model had a pseudo- $\mathrm{R}^{2}$ of 0.082 and the residuals were randomly distributed (table 6\&7).

Mean species richness at Silver Lake was 0.30. Regarding mean species richness in Silver Lake, the model with the highest performance consisted of water depth, distance from shore, and silt as the explanatory variables; the $p s e u d o R^{2}$ for this model was 0.357 (table 2). Both water depth and distance from shore were negatively related to the species richness in Silver Lake. GLR's slope coefficient was 2.8882 for water depth and -0.0085 for distance from shore (table 3 ). In the best-fit model, silt was positively related to species richness and had a slope coefficient of 0.0510 (table 3 ). Residuals of the GLR were found to be randomly distributed by the Moran's I test $(Z=0.580, P=0.562)$ (table 3 ).

Mean species richness at Clear Lake was 0.08 . The best-fit model for mean species richness in Clear Lake consisted of distance from shore as the only significant explanatory variable. This model had a pseudo$\mathrm{R}^{2}$ of 0.313 (table 2). Distance from shore was negatively related to the species richness, with a slope coefficient of -0.0424 (table 3 ). Residuals of the best-fit model were randomly distributed according Moran's I ( $Z=-1.383, P=0.167)$ (table 3).

\section{Discussion}


The factors that affected mean species richness were water depth, sample distance from shore, and percent silt. All mean species richness models with significant results had relatively high pseudo- $\mathrm{R}^{2}$ values (table $2 \& 3$ ), and selected explanatory variables accounted for between $25 \%$ and $40 \%$ of the variation in species richenss in all significant models.

Water depth was related to mean species richness in three of the five lakes in Sibley County (table 3). In all three models, water depth was negatively related to mean species richness. Negative relationships between water depth and mean species richness are primarily driven by the reduction of light availability at increasing depths (Barko et al., 1986; Lacoul \& Freedman, 2006; Bornette \& Puijalon, 2011). In both Schilling Lake and High Island Lake, mean species richness declined as depth increased. This supports the hypothesis that light attenuation increases as depth increases, which inhibits the richness and frequency of macrophytes at greater depth. Both Schilling Lake and High Island Lake had relatively deep secchi depths (table 1), and 95\% of all macrophytes were found growing within $2 \mathrm{~m}$ of the surface in both lakes. Silver Lake also had depth as a significant variable (table 3), however, Silver Lake was dominated by Nymphaea odorata Aiton (fragrant waterlily), a floating-leaf macrophyte, whereas Schilling lake and High Island Lake were dominated by submersed aquatic vegetation (curlyleaf pondweed and sago pondweed). The dominance of fragrant waterlily in Silver Lake is likely due to the lakes's high turbidity (table 1), Floating-leaf macrophytes are able to attenuate light at the surface of the water, which negates the growth inhibition of turbidity (Lacoul \& Freedman, 2006). Prior to the production of floating leaves, fragrant waterlily produces submersed growth that is subject to the effects of turbidity, which is probably a reason why fragrant waterlily is usually relegated to shallow water (Lacoul \& Freedman, 2006). This zonation of floating leaf macrophytes was observed in Silver Lake, as nearly all macrophytes surveyed were found at depths shallower than $1.5 \mathrm{~m}$. This evidence suggests that water depth is a major limiting factor for mean species richness in Silver Lake.

Similar to how depth limits mean species richness of Silver Lake, there is also a significant negative relationship between distance from shore and mean species richness in Silver Lake (table 3). This is likely because fragrant waterlily is the dominant macrophyte. Floating leaf macrophytes are usually distributed much closer to shore than submersed macrophytes, which would explain why distance from shore is a significant predictor in Silver Lake mean species richness (Lacoul \& Freedman, 2006). Additionally, submersed macrophytes can inhabit areas that are deeper and further from shore than free-floating macrophytes, which would explain why distance from shore is not a significant variable in Schilling and High Island Lake (Lacoul \& Freedman, 2006). In the Clear Lake model, distance from shore is the only significant variable that affects the richness of macrophtyes (table 3). Distance from shore is highly influential in Clear Lake's mean species richness because its bottom is deeper than the other lakes in the study, and the water clarity is low. Additionally, water depth deepened dramatically very close to the shore. This steep slope in combination with turbid waters greatly limited the distance from shore that rooted macrophytes could grow in Clear Lake.

The only sediment factor related to mean species richness was percent silt in Schilling Lake and Silver Lake (table 3). Silt consists of fine-grained particles that readily re-suspend when significant wave action 
is present (Barko et al., 1991; Koch, 2001). When suspended in the water column, silt contribute significantly to turbidity which limits light availability for submersed macrophytes (Zhu et al., 2015). However, higher silt content can improve the nutrient availability of the sediment by raising the CEC (Gerbersdorf et al., 2007). This tradeoff causes silt content of the sediment to exhibit both facultative and inhibitory effects on the abundance and distribution of aquatic macrophytes; and whether percent silt is positively or negatively related to sediment silt is largely species-specific (Koch, 2001). Both relationships were observed in this study. Silt percent was negatively related to the species richness in Schilling Lake, which was dominated by curlyleaf pondweed. Additionally, the presence of curlyleaf pondweed in Schilling Lake was negatively related to silt percent. Data from these models suggest that silt in the sediment inhibits the growth of curlyleaf pondweed, because it contributes to turbidity as it is suspended in the water column. Conversely, in the fragrant waterlily dominated Silver Lake, mean species richness was positively related to percent silt in the sediment (table 3). Fragrant waterlily produces thick rhizomes that support large floating leaves. Once the floating leave reach the surface of the water, fragrant waterlily no longer experiences the detrimental effects of turbidity, which is why fragrant waterlily and other morphologically similar species often dominate shallow, turbid lakes (Lacoul \& Freedman, 2006). The positive relationship observed in Silver Lake suggests that not only is fragrant waterlily not inhibited by suspended silt, but it benefits from higher sediment nutrient availability caused by silts greater cation exchange capasity (Gerbersdorf et al., 2007). Similarly, late season presence and absence of sago pondweed was positively related to silt (table 7). This relationship was also observed in previous research in southern MN lakes (Case \& Madsen, 2004); Madsen et al. 2006).

In Heron Lake (Jackson County, MN, USA) researchers found that the frequency of sago pondweed was positively related to percent silt in the sediment (Case \& Madsen, 2004). Although sago pondweed is a submersed aquatic macrophyte, like curlyleaf pondweed, unlike curlyleaf pondweed, it is a prolific tuber producer (Kantrud, 1990; Wersal et al., 2006). In Swan Lake (Nicollet County, MN, USA) researchers observed a preference for siltier sediment exhibited by Vallisneria americana Michx. (American eelgrass), another species with high root biomass (Madsen et al., 2006). Similar to fragrant waterlily, sago pondweed and American eelgrass are likely benefitting from higher CEC of silt rich soils, which is beneficial for plants with high root biomass. Ultimately, evidence from this study and previous studies suggest that the effect silt has on the abundance and distribution of aquatic macrophytes is highly species-specific.

In Schilling Lake, the dominant submersed macrophyte was curlyleaf pondweed in the early season. The model for factors that affect early season presence and absence of curlyleaf pondweed in Schilling Lake had water depth and percent silt as significant, explanatory variables, just like the model for mean species richness in Schilling Lake (table 5). However, the early season curlyleaf pondweed model also had percent SOM as a significant explanatory variable, which was a positive predictor of the presence of curlyleaf pondweed in Schilling Lake (table 5). This relationship contradicts the literature, which consistently cites SOM as an inhibitor of rooted macrophyte growth (Barko \& Smart, 1986; Koch, 2001). However, previous studies have found that the inhibitory effects of SOM plateau after about $20 \%$ SOM (Barko \& Smart, 1986), and in Schilling Lake, the mean percent SOM was $27.77 \%$ ( $s=10.02 \%$ ). 
Additionally, a mesocosm study found that different species of submersed macrophytes express differential susceptibility to the inhibitory effects of SOM (Silveira \& Thomaz, 2015). It is possible that curlyleaf pondweed is not as susceptible to growth inhibition by SOM. Future research should assess relationships between curlyleaf pondweed and SOM in greater detail.

\section{Conclusions}

Overall, model results for factors that affect mean species richness in the study lakes show depth as the primary factor. However, in lakes with high turbidity, the effect of water depth on mean species richness diminished and distance from shore was instead found to be a significant variable. Sediment silt also had significant, negative effects on mean species richness in Schilling Lake, however, in Silver Lake, which was dominated by a floating-leaf macrophyte, silty sediments promoted the mean species richness. When predicting the distribution of macrophytes in shallow lake systems, water depth should be the principal factor accounted for. Lakes in which depth was a significant predictor had frequency of macrophytes greatly diminish at depths greater than $2 \mathrm{~m}$, due to the reduced light availability. Distance from shore will also need to be accounted for as some of the lakes showed a reduction of mean species richness and frequency as distance from shore increased. This study determined that the only sediment factor that was a significant predictor of macrophtye distribution was silt. However, whether silt promotes or inhibits macrophyte frequency and richness depends on species composition. Silt contributes to turbidity in some systems which can negatively affect submersed macrophytes. However, in systems where floating leaf macrophytes are dominant, the distribution of macrophytes may be positively related silt content, with the higher CEC of the silt as a possible explanation.

\section{Declarations}

\section{Funding}

This research was funded by the Sibley County Soil and Water Conservation District through funds allocated from the Aquatic Invasive Species Prevention Aid program.

Conflict of interest

There are no conflict of interests.

Data availability

Data that support the findings of this study are available from the corresponding author, upon reasonable request.

\section{Code availability}

Not applicable 
Ethics approval

Not applicable

Consent to participate

Not applicable

Consent for publication

The authors consent to have this manuscript published if accepted.

Authors' Contributions

SS - conducted the research as part of his MS degree, analyzed data, and was the primary writer of the manuscript.

RW - was the chair of the graduate committee, assisted in field data collection, and was a major contributor in data analysis and manuscript preparation.

JF - was a major contributor in spatial model creation and data analysis, he was also a major contributor in manuscript preparation.

\section{ACKNOWLEDGEMENTS}

Thanks to the Sibley County Soil and Water Conservation District for funding this study. Thanks to Joel Wurscher and Jack Bushman from Sibley County Soil and Water Conservation for logistic and informational contributions to this study. Thanks to the following Aquatic Weed Science Lab Technicians: Alex Green, Amber Fistler, Ashley Kasper, BaileyClaire Scott, Franklin Rogers, June Somsanith, Kari Solfest, Sara Ademi, and Vincent McKnight.

\section{References}

1. Andersson, B., 2001. Macrophyte development and habitat characteristics in Sweden's large lakes. AMBIO: A Journal of the Human Environment Royal Swedish Academy of Sciences 30: 503-513.

2. Bakker, E. S., E. Van Donk, S. A. J. Declerck, N. R. Helmsing, B. Hidding, \& B. A. Nolet, 2010. Effect of macrophyte community composition and nutrient enrichment on plant biomass and algal blooms. Basic and Applied Ecology 11: 432-439.

3. Barko, J. W., M. S. Adams, \& N. L. Clesceri, 1986. Environmental factors and their consideration in the management of submersed aquatic vegetation: a review. Journal of Aquatic Plant Management 24: $1-10$.

4. Barko, J. W., D. Gunnison, \& S. R. Carpenter, 1991. Sediment dynamics with submersed macrophyte growth and community dynamics. Aquatic Botany 41: 41-65. 
5. Barko, J. W., \& R. M. Smart, 1986. Sediment-related mechanisms of growth limitation in submersed macrophytes. Ecology 67: 1328-1340.

6. Blindow, I., 1992. Decline of charophytes during eutrophication: comparison with angiosperms. Freshwater Biology 28: 9-14.

7. Bornette, G., \& S. Puijalon, 2011. Response of aquatic plants to abiotic factors: a review. Aquatic Sciences 73: 1-14.

8. Bouyoucos, G. J., 1962. Hydrometer method improved for making particle size analysis of soils. Agronomy Journal 54: 464-465.

9. Case, M. L., \& J. D. Madsen, 2004. Factors limiting the growth of Stuckenia pectinata (sago pondweed) in Heron Lake, Minnesota. Journal of Freshwater Ecology 19: 17-23.

10. Chambers, P. A., \& J. Kaiff, 1985. Depth distribution and biomass of submersed aquatic macrophyte communities in relation to secchi depth. Canadian Journal of Fisheries and Aquatic Sciences NRC Research Press Ottawa, Canada, https://cdnsciencepub.com/doi/abs/10.1139/f85-090.

11. Chen, Y., 2016. Spatial autocorrelation approaches to testing residuals from least squares regression. PLOS ONE Public Library of Science 11: e0146865.

12. Cheruvelil, K. S., \& P. A. Soranno, 2008. Relationships between lake macrophyte cover and lake and landscape features. Aquatic Botany 88: 219-227.

13. Cox, M. C., R. M. Wersal, J. D. Madsen, P. D. Gerard, \& M. L. Tagert, 2014. Assessing the aquatic plant community within the Ross Barnett Reservoir, Mississippi. Invasive Plant Science and Management 7: $375-383$.

14. Dean, W. E., 1974. Determination of carbonate and organic matter in calcareous sediments and sedimentary rocks by loss on ignition; comparison with other methods. Journal of Sedimentary Research 44: 242-248.

15. Dibble, E. D., \& F. M. Pelicice, 2010. Influence of aquatic plant-specific habitat on an assemblage of small neotropical floodplain fishes. Ecology of Freshwater Fish 19: 381-389.

16. Fleming, J. P., R. M. Wersal, J. D. Madsen, \& E. D. Dibble, 2021. Weak non-linear influences of biotic and abiotic factors on invasive macrophyte occurrence. Aquatic Invasions 16: 349-364.

17. Gerbersdorf, S. U., T. Jancke, \& B. Westrich, 2007. Sediment properties for assessing the erosion risk of contaminated riverine sites. An approach to evaluate sediment properties and their covariance patterns over depth in relation to erosion resistance. First investigations in natural sediments. Journal of Soils and Sediments 7: 25-35.

18. Guntenspergen, G., S. Peterson, S. Leibowitz, \& L. Cowardin, 2002. Indicators of wetland condition for the Prairie Pothole Region of the United States. Environmental monitoring and assessment; An International Journal Devoted to Progress in the Use of Monitoring Data in Assessing Environmental Risks to Man and the Environment 78: 229-252.

19. Heiri, O., A. Lotter, \& G. Lemcke, 2001. Loss on ignition as a method for estimating organic and carbonate content in sediments: reproducibility and comparability of results. Journal of Paleolimnology 25: 101-110. 
20. James, W. F., E. P. Best, \& J. W. Barko, 2004. Sediment resuspension and light attenuation in Peoria Lake: can macrophytes improve water quality in this shallow system?. Hydrobiologia 515: 193-201.

21. Kantrud, H. A., 1990. Sago pondweed (Potamogeton pectinatus L.): A literature review. Washington, DC: 1-88, http://pubs.er.usgs.gov/publication/2000134.

22. Koch, E. W., 2001. Beyond light: Physical, geological, and geochemical parameters as possible submersed aquatic vegetation habitat requirements. Estuaries 24: 1-17.

23. Körner, S., \& A. Nicklisch, 2002. Allelopathic growth inhibition of selected phytoplankton species by submerged macrophytes. Journal of Phycology 38: 862-871.

24. Lacoul, P., \& B. Freedman, 2006. Environmental influences on aquatic plants in freshwater ecosystems. Environmental Reviews NRC Research Press Ottawa, Canada, https://cdnsciencepub.com/doi/abs/10.1139/a06-001.

25. Madsen, J. D., J. A. Bloomfield, J. W. Sutherland, L. W. Eicher, \& C. W. Boylen, 1996. The aquatic macrophyte community of Onondaga Lake: field survey and plant growth bioassays of lake sediments. Lake and Reservoir Management 12: 73-79.

26. Madsen, J. D., P. A. Chambers, W. F. James, E. W. Koch, \& D. F. Westlake, 2001. The interaction between water movement, sediment dynamics and submersed macrophytes. Hydrobiologia 444: 7184.

27. Madsen, J. D., R. M. Wersal, M. Tyler, \& P. D. Gerard, 2006. The distribution and abundance of aquatic macrophytes in Swan Lake and Middle Lake, Minnesota. Journal of Freshwater Ecology 21: 421429.

28. Madsen, J. D., R. M. Wersal, \& T. E. Woolf, 2015. Operational control of Eurasian watermilfoil (Myriophyllum spicatum) and impacts to the native submersed aquatic macrophyte community in Lake Pend Oreille, Idaho. Invasive Plant Science and Management 8: 219-232.

29. Madsen, J., R. Stewart, K. Getsinger, R. Johnson, R. Wersal, \& J. Madsen, 2008. Aquatic plant communities in Waneta Lake and Lamoka Lake, New York. Northeastern Naturalist 15: 97-110.

30. National Resource Conservation Service, 1997. Soil Survey of Sibley County, Minnesota. United States Department of Agriculture: 1-175.

31. Radomski, P., \& D. Perleberg, 2012. Application of a versatile aquatic macrophyte integrity index for Minnesota lakes. Ecological Indicators 20: 252-268.

32. Rooney, N., \& J. Kalff, 2000. Inter-annual variation in submerged macrophyte community biomass and distribution: the influence of temperature and lake morphometry. Aquatic Botany 68: 321-335.

33. Scheffer, M., 1999. The effect of aquatic vegetation on turbidity; how important are the filter feeders?. Hydrobiologia 408/409: 307-316.

34. Scheffer, M., 2004. Ecology of Shallow Lakes. Kluwer Academic Publishers, Dordrecht, The Netherlands.

35. Schmid, S. A., \& R. M. Wersal, 2021. Aquatic macrophyte community shifts in five shallow lakes in Sibley County, MN. Journal of Aquatic Plant Management in press. 
36. Sibley County, 2018. Statistics - Economic Developement. Sibley County, MN. , https://www.co.sibley.mn.us/economic_development/visitors/about_us/statistics/index.php.

37. Silveira, M. J., \& S. M. Thomaz, 2015. Growth of a native versus an invasive submerged aquatic macrophyte differs in relation to mud and organic matter concentrations in sediment. Aquatic Botany 124: 85-91.

38. Takamura, N., Y. Kadono, M. Fukushima, M. Nakagawa, \& B. O. Kim, 2003. Effects of aquatic macrophytes on water quality and phytoplankton communities in shallow lakes. Ecological Research Blackwell Publishing Ltd., Tokyo, United Kingdom 18: 381-395.

39. Waters, N. M., \& C. R. S. Giovanni, 2002. Distribution and diversity of benthic macroinvertebrates associated with aquatic macrophytes. Journal of Freshwater Ecology Taylor \& Francis 17: 223-232.

40. Wersal, R. M., J. D. Madsen, \& J. C. Cheshier, 2010. Aquatic plant monitoring In Noxon Rapids Reservoir and Cabinet Gorge Reservoir for 2010. Geosystems Research Institute: 18.

41. Wersal, R. M., B. R. McMillan, \& J. D. Madsen, 2005. Food habits of dabbling ducks during fall migration in a prairie pothole system, Heron Lake, Minnesota. The Canadian Field-Naturalist 119: 546-550.

42. Wersal, R., J. Madsen, B. McMillan, \& P. Gerard, 2006. Environmental factors affecting biomass and distribution of Stuckenia pectinata in the Heron Lake System, Minnesota, USA. Wetlands 26: 313321.

43. Woolf, T. E., \& J. D. Madsen, 2003. Seasonal biomass and carbohydrate allocation patterns in southern Minnesota curlyleaf pondweed populations. Journal of Aquatic Plant Management 41: $113-118$.

44. Wu, D., \& Z. Hua, 2014. The effect of vegetation on sediment resuspension and phosphorus release under hydrodynamic disturbance in shallow lakes. Ecological Engineering 69: 55-62.

45. Zhu, M., G. Zhu, L. Nurminen, T. Wu, J. Deng, Y. Zhang, B. Qin, \& A.-M. Ventelä, 2015. The influence of macrophytes on sediment resuspension and the effect of associated nutrients in a shallow and large lake (Lake Taihu, China). PLOS ONE 10: e0127915.

\section{Tables}

Table 1. Physical and geographic properties of the five lakes in Sibley Co., MN, USA during the 2019 growing season. 


\begin{tabular}{llllll} 
& $\begin{array}{l}\text { Latitude } \\
\left({ }^{\circ}\right)\end{array}$ & $\begin{array}{l}\text { Longitude } \\
\left({ }^{\circ}\right)\end{array}$ & $\begin{array}{l}\text { Total area } \\
\left(\mathrm{km}^{2}\right)\end{array}$ & $\begin{array}{l}\text { Average depth } \\
(\mathrm{cm})\end{array}$ & $\begin{array}{l}\text { Sechi depth } \\
(\mathrm{cm})\end{array}$ \\
\hline $\begin{array}{l}\text { High Island } \\
\text { Lake }\end{array}$ & 44.6678 & -94.2103 & 6.99 & 167.6 & 149 \\
\hline Titlow Lake & 44.5696 & -94.2000 & 3.60 & 149.4 & 22 \\
\hline Schilling Lake & 44.6959 & -94.2103 & 3.55 & 167.6 & 86 \\
\hline Silver Lake & 44.6185 & -93.9710 & 2.92 & 164.6 & 10 \\
\hline Clear Lake & 44.4566 & -94.5147 & 2.04 & 228.6 & 29
\end{tabular}

Table 2. GLR results for factors that affect mean species richness in the five survey lakes, Sibley Co., MN, USA 2019. 
Lake

Model $^{\mathrm{a}}$

High Island

Lake

Titlow Lake

Schilling

Lake

Silver Lake

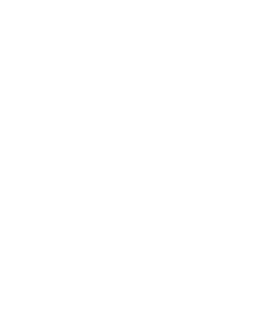

Clear Lake

CLAY

\begin{tabular}{l} 
DEPTH \\
\hline DEPTH+DISTANCE \\
\hline DEPTH+DISTANCE+SAND \\
\hline DEPTH+DISTANCE+SAND+CLAY \\
\hline DEPTH+DISTANCE+SAND+SILT+CLAY \\
\hline DEPTH+DISTANCE+SAND+SILT+CLAY+SOM
\end{tabular}

SILT+CLAY

DEPTH+SILT+CLAY

DEPTH+SAND+SILT+CLAY

DEPTH+DISTANCE+SAND+SILT+CLAY

DEPTH+DISTANCE+SAND+SILT+CLAY+SOM

DEPTH+SILT

DEPTH+DISTANCE+SILT

DEPTH+DISTANCE+SILT+SOM

DEPTH+DISTANCE+SILT+CLAY+SOM

DEPTH+DISTANCE+SAND+SILT+CLAY+SOM

DEPTH+DISTANCE+SILT

DEPTH+DISTANCE+SILT+CLAY

DEPTH+DISTANCE+SILT+CLAY+SOM

DEPTH+SILT

DEPTH+DISTANCE+SAND+SILT+CLAY+SOM

DISTANCE
DISTANCE+SILT

DEPTH+DISTANCE+SILT

DEPTH+DISTANCE+SILT+SOM

DEPTH+DISTANCE+SILT+CLAY+SOM

DEPTH+DISTANCE+SAND+SILT+CLAY+SOM

Page $17 / 26$

$\begin{array}{lll}\mathrm{AlCc}^{\mathrm{b}} \quad \triangle \mathrm{AlCc}^{\mathrm{C}} & \begin{array}{l}\text { Pseudo- Rank } \\ \mathrm{R}^{2}\end{array}\end{array}$

\begin{tabular}{llll}
439.18 & 0.00 & 0.281 & 1 \\
\hline 440.59 & 1.41 & 0.272 & 2 \\
\hline 442.22 & 3.04 & 0.275 & 3 \\
444.09 & 4.91 & 0.271 & 4 \\
445.90 & 6.72 & 0.270 & 5 \\
\hline 447.88 & 8.70 & 0.267 & 6
\end{tabular}

$\begin{array}{llll}150.48 & 0.00 & 0.010 & 1\end{array}$

$\begin{array}{llll}151.67 & 1.19 & 0.007 & 2\end{array}$

$\begin{array}{llll}153.23 & 2.75 & 0.004 & 3\end{array}$

$\begin{array}{llll}154.79 & 4.31 & -0.001 & 4\end{array}$

$\begin{array}{llll}156.70 & 6.22 & -0.004 & 5\end{array}$

$\begin{array}{llll}158.14 & 7.66 & -0.003 \quad 6\end{array}$

$\begin{array}{llll}280.53 & 0.05 & 0.285 & 1\end{array}$

$\begin{array}{llll}280.48 & 0.00 & 0.315 & 2\end{array}$

$\begin{array}{llll}281.15 & 0.67 & 0.328 & 3\end{array}$

$\begin{array}{llll}282.47 & 1.99 & 0.314 & 4\end{array}$

$\begin{array}{llll}285.27 & 4.79 & 0.306 & 5\end{array}$

$\begin{array}{llll}111.03 & 1.08 & 0.357 & 1\end{array}$

$\begin{array}{llll}109.95 & 0.00 & 0.408 & 2\end{array}$

$\begin{array}{llll}111.07 & 1.12 & 0.402 & 3\end{array}$

$\begin{array}{llll}113.60 & 3.65 & 0.400 & 4\end{array}$

$\begin{array}{llll}112.36 & 2.41 & 0.389 & 5\end{array}$

$\begin{array}{llll}36.80 & 0.00 & 0.313 & 1\end{array}$

$\begin{array}{llll}36.97 & 0.17 & 0.298 & 2\end{array}$

$\begin{array}{llll}37.86 & 1.06 & 0.273 & 3\end{array}$

$\begin{array}{llll}40.38 & 3.58 & 0.278 & 4\end{array}$

$\begin{array}{llll}42.83 & 6.03 & 0.270 \quad 5\end{array}$

$\begin{array}{llll}44.82 & 8.02 & 0.262 & 6\end{array}$


a Model variables are water depth (DEPTH), distance from shore (DISTANCE), percent sand (SAND), percent silt (SILT), percent clay (CLAY), and percent sediment organic matter (SOM).

${ }^{\mathrm{b}}$ Corrected Akaike's Information Criterion

${ }^{\mathrm{C}}$ The difference between the lowest AICc value and the respective AICc value

Table 3. Statistics for explanatory variables and Moran's I results on residuals of the best-fit models for factors that affect mean species richness in the five study lakes, Sibley Co., MN, USA 2019. Best-fit models were determined via GLR model selection.

\begin{tabular}{|c|c|c|c|c|c|c|}
\hline \multicolumn{5}{|c|}{ Explanatory variable statistics } & \multicolumn{2}{|c|}{ Moran's I } \\
\hline Lake & Variable ${ }^{a}$ & Slope coefficient & Standard error & P-value & Z-score & P-value \\
\hline High Island Lake & DEPTH & -1.5416 & 0.1883 & $<0.001$ & 4.498 & $<0.001$ \\
\hline Titlow Lake & CLAY & -0.0242 & 0.0163 & 0.137 & 1.837 & 0.066 \\
\hline \multirow[t]{2}{*}{ Schilling Lake } & DEPTH & -0.8854 & 0.2005 & $<0.001$ & \multirow[t]{2}{*}{3.708} & \multirow[t]{2}{*}{$<0.001$} \\
\hline & SILT & -0.0284 & 0.0083 & $<0.001$ & & \\
\hline \multirow[t]{3}{*}{ Silver Lake } & DEPTH & -2.8882 & 0.4929 & $<0.001$ & \multirow[t]{3}{*}{0.580} & \multirow[t]{3}{*}{0.562} \\
\hline & DISTANCE & -0.0085 & 0.0043 & 0.047 & & \\
\hline & SILT & 0.0510 & 0.0153 & $<0.001$ & & \\
\hline Clear Lake & DISTANCE & -0.0424 & 0.0156 & 0.007 & -1.383 & 0.167 \\
\hline
\end{tabular}

Table 4. GLR results for the factors that affect early season presence/absence of curlyleaf pondweed and sago pondweed in Schilling Lake, Sibley Co., MN, USA 2019. 


\begin{tabular}{|c|c|c|c|c|c|}
\hline Species & Model $^{\mathrm{a}}$ & $\mathrm{AlCc}^{\mathrm{b}}$ & $\triangle \mathrm{AICC^{ \textrm {C } }}$ & $\begin{array}{l}\text { Pseudo- } \\
\mathrm{R}^{2}\end{array}$ & Rank \\
\hline \multirow{5}{*}{$\begin{array}{l}\text { Curlyleaf } \\
\text { pondweed }\end{array}$} & DEPTH+SILT+SOM & 181.45 & 0.00 & 0.143 & 1 \\
\hline & DEPTH+SILT & 183.59 & 2.14 & 0.122 & 2 \\
\hline & DEPTH+DISTANCE+SILT+SOM & 181.67 & 0.22 & 0.145 & 3 \\
\hline & DEPTH+DISTANCE+SAND+SILT+SOM & 183.41 & 1.96 & 0.141 & 4 \\
\hline & DEPTH+DISTANCE+SAND+SILT+CLAY+SOM & 185.23 & 3.78 & 0.135 & 5 \\
\hline \multirow{6}{*}{$\begin{array}{l}\text { Sago } \\
\text { pondweed }\end{array}$} & SILT & 70.96 & 0.00 & -0.003 & 1 \\
\hline & SILT+CLAY & 72.19 & 1.23 & -0.005 & 2 \\
\hline & DISTANCE+SILT+CLAY & 73.71 & 2.75 & -0.012 & 3 \\
\hline & DISTANCE+SILT+CLAY+SOM & 75.54 & 4.58 & -0.017 & 4 \\
\hline & DEPTH+DISTANCE+SILT+CLAY+SOM & 77.51 & 6.55 & -0.023 & 5 \\
\hline & DEPTH+DISTANCE+SAND+SILT+CLAY+SOM & 80.5 & 9.54 & -0.030 & 6 \\
\hline
\end{tabular}

${ }^{a}$ Model variables are water depth (DEPTH), distance from shore (DISTANCE), percent sand (SAND), percent silt (SILT), percent clay (CLAY), and percent sediment organic matter (SOM).

${ }^{\mathrm{b}}$ Corrected Akaike's Information Criterion

${ }^{\mathrm{C}}$ The difference between the lowest AICc value and the respective AICc value

Table 5. Statistics for explanatory variables and Moran's I results on residuals of the best-fit models for factors that affect early season presence/absence of curlyleaf pondweed and sago pondweed in Schilling Lake, Sibley Co., MN, USA 2019. Best-fit models were determined via GLR model selection.

\begin{tabular}{|c|c|c|c|c|c|c|}
\hline \multicolumn{5}{|c|}{ Explanatory variable statistics } & \multicolumn{2}{|c|}{ Moran's I } \\
\hline Species & Variable ${ }^{a}$ & $\begin{array}{l}\text { Slope } \\
\text { coefficient }\end{array}$ & $\begin{array}{l}\text { Standard } \\
\text { Error }\end{array}$ & $\begin{array}{l}\mathrm{P} \text { - } \\
\text { value }\end{array}$ & z-score & P-value \\
\hline \multirow{3}{*}{$\begin{array}{l}\text { Curlyleaf } \\
\text { pondweed }\end{array}$} & DEPTH & -1.4582 & 0.5127 & 0.004 & 3.959 & $<0.001$ \\
\hline & SILT & -0.0613 & 0.0170 & $<0.001$ & & \\
\hline & SOM & 0.0367 & 0.0186 & 0.048 & & \\
\hline Sago pondweed & SILT & 0.0167 & 0.0275 & 0.544 & -1.085 & 0.278 \\
\hline
\end{tabular}

${ }^{a}$ Model variables are water depth (DEPTH), percent silt (SILT), and percent sediment organic matter (SOM). 
Table 6. GLR results for the factors that affect late season presence/absence of curlyleaf pondweed and sago pondweed in Schilling Lake, Sibley Co., MN, USA 2019.

\begin{tabular}{|c|c|c|c|c|c|c|c|}
\hline Species & \multicolumn{3}{|c|}{ Model $^{\mathrm{a}}$} & $\mathrm{AlCc}^{\mathrm{b}}$ & $\triangle \mathrm{AlCc}^{\mathrm{C}}$ & Pseudo-R ${ }^{2}$ & Rank \\
\hline \multirow{6}{*}{$\begin{array}{l}\text { Curlyleaf } \\
\text { pondweed }\end{array}$} & \multicolumn{3}{|c|}{ DEPTH } & 118.56 & 0.00 & 0.070 & 1 \\
\hline & \multicolumn{3}{|c|}{ DEPTH+DISTANCE } & 119.62 & 1.06 & 0.079 & 2 \\
\hline & \multicolumn{3}{|c|}{ DEPTH+DISTANCE+SAND } & 120.99 & 2.43 & 0.085 & 3 \\
\hline & \multicolumn{3}{|c|}{ DEPTH+DISTANCE+SAND+SOM } & 122.97 & 4.40 & 0.086 & 4 \\
\hline & \multicolumn{3}{|c|}{ DEPTH+DISTANCE+SAND+SILT+SOM } & 125.03 & 6.46 & 0.087 & 5 \\
\hline & \multicolumn{3}{|c|}{ DEPTH+DISTANCE+SAND+SILT+CLAY+SOM } & 127.23 & 8.67 & 0.087 & 6 \\
\hline \multirow{6}{*}{$\begin{array}{l}\text { Sago } \\
\text { pondweed }\end{array}$} & \multicolumn{3}{|c|}{ DEPTH+SILT } & 175.66 & 0.00 & 0.082 & 1 \\
\hline & \multicolumn{3}{|c|}{ DEPTH } & 179.50 & 3.83 & 0.050 & 2 \\
\hline & \multicolumn{3}{|c|}{ DEPTH+DISTANCE+SILT } & 177.63 & 1.97 & 0.083 & 3 \\
\hline & \multicolumn{3}{|c|}{ DEPTH+DISTANCE+SILT+CLAY } & 179.69 & 4.03 & 0.083 & 4 \\
\hline & \multicolumn{3}{|c|}{ DEPTH+DISTANCE+SILT+CLAY+SOM } & 181.78 & 6.12 & 0.084 & 5 \\
\hline & \multicolumn{3}{|c|}{ DEPTH+DISTANCE+SAND+SILT+CLAY+SOM } & 183.98 & 8.32 & 0.084 & 6 \\
\hline \multirow{2}{*}{\multicolumn{8}{|c|}{$\begin{array}{l}\text { a Model variables are water depth (DEPTH), distance from shore (DISTANCE), percent sand (SAND), } \\
\text { percent silt (SILT), percent clay (CLAY), and percent sediment organic matter (SOM). }\end{array}$}} \\
\hline & & & & & & & \\
\hline \multicolumn{8}{|c|}{${ }^{\mathrm{C}}$ The difference between the lowest AICc value and the respective AICc value } \\
\hline & \multicolumn{3}{|c|}{ Explanatory variable statistics } & & & \multicolumn{2}{|l|}{ Moran's I } \\
\hline Species & & Variable & $\begin{array}{l}\text { Slope } \\
\text { coefficient }\end{array}$ & dard & P-value & z-score & P-value \\
\hline $\begin{array}{l}\text { Curlyleaf } \\
\text { pondweed }\end{array}$ & & DEPTH & -0.595 & & 0.005 & 4.618 & $<0.001$ \\
\hline \multirow{2}{*}{\multicolumn{2}{|c|}{ Sago pondweed }} & DEPTH & -0.585 & & 0.018 & 0.014 & 0.989 \\
\hline & & SILT & 0.037 & & $<0.001$ & & \\
\hline
\end{tabular}


${ }^{a}$ Model variables are water depth (DEPTH) and percent silt (SILT).

\section{Figures}

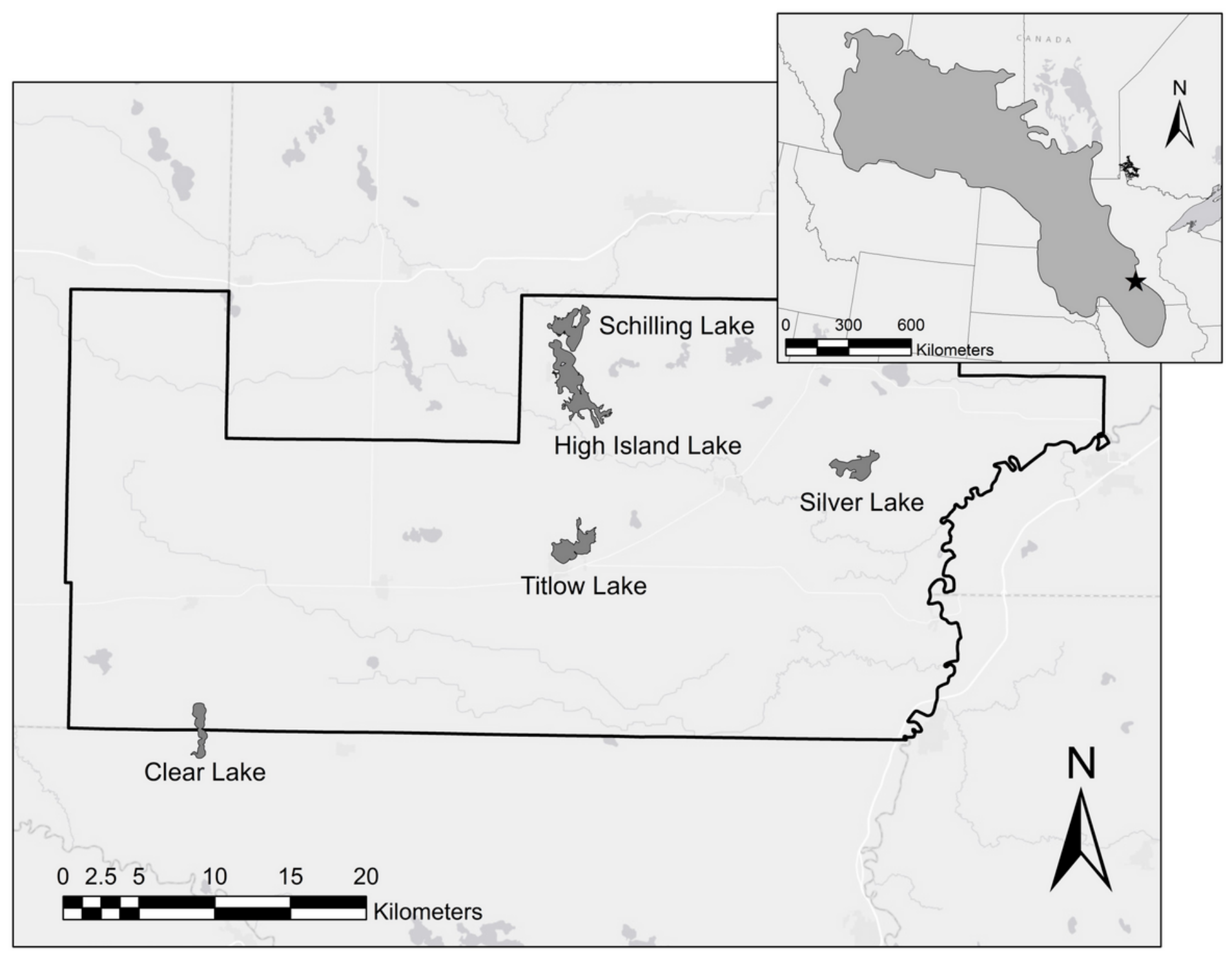

Figure 1

The five lakes in Sibley Co., MN that were surveyed during the 2019 growing season. Black line indicates the border of Sibley Co. Inset shows position of Sibley Co. (black star) in the Prairie Pothole Region located in Midwestern North America. 


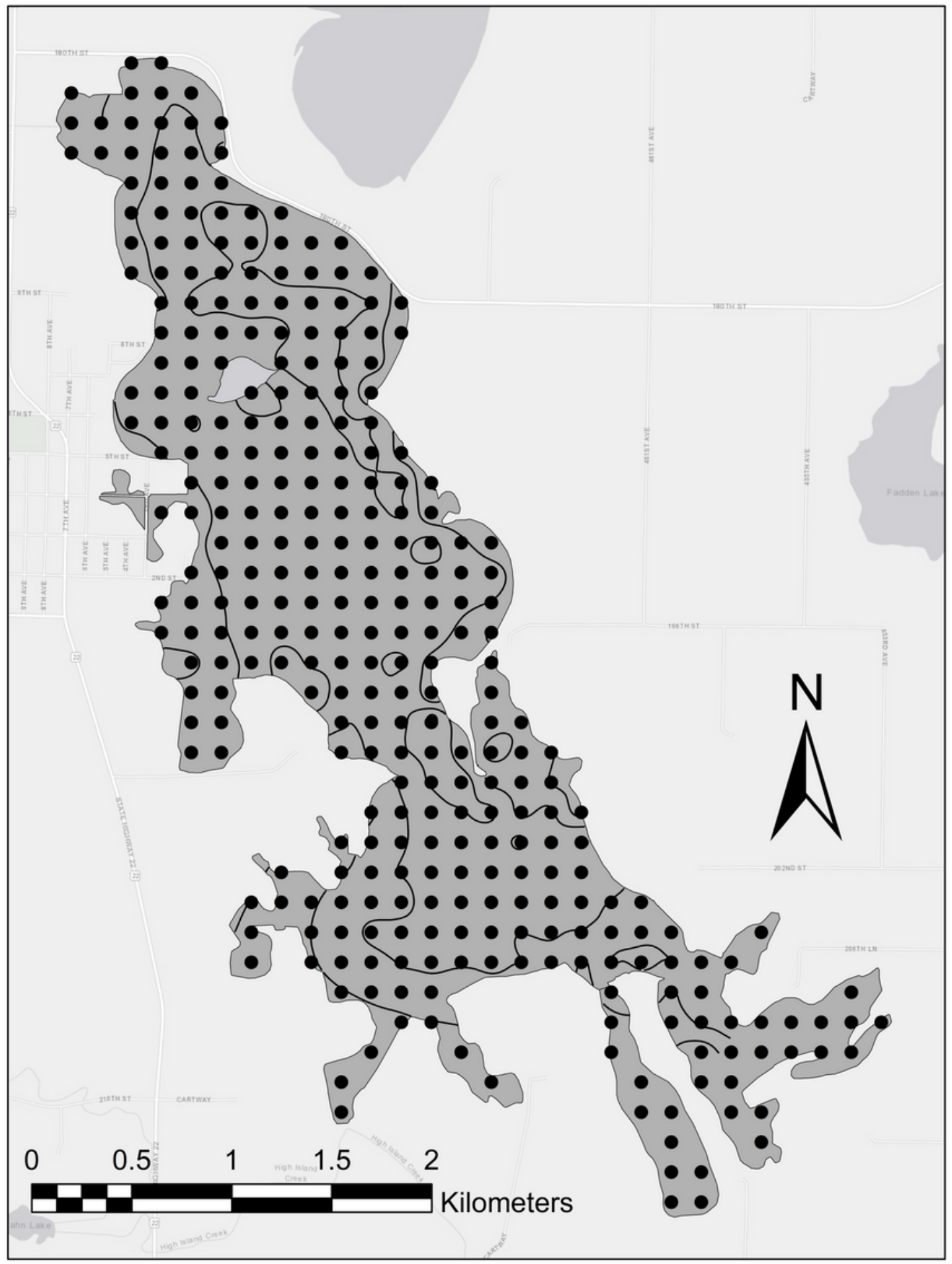

Figure 2

Grid of survey points in High Island Lake for surveys during the 2019 growing season in Sibley Co., MN. Contour lines represent changes of depth by $0.5 \mathrm{~m}$ intervals. Contour lines derived from depth data at sample points $(n=318)$. 


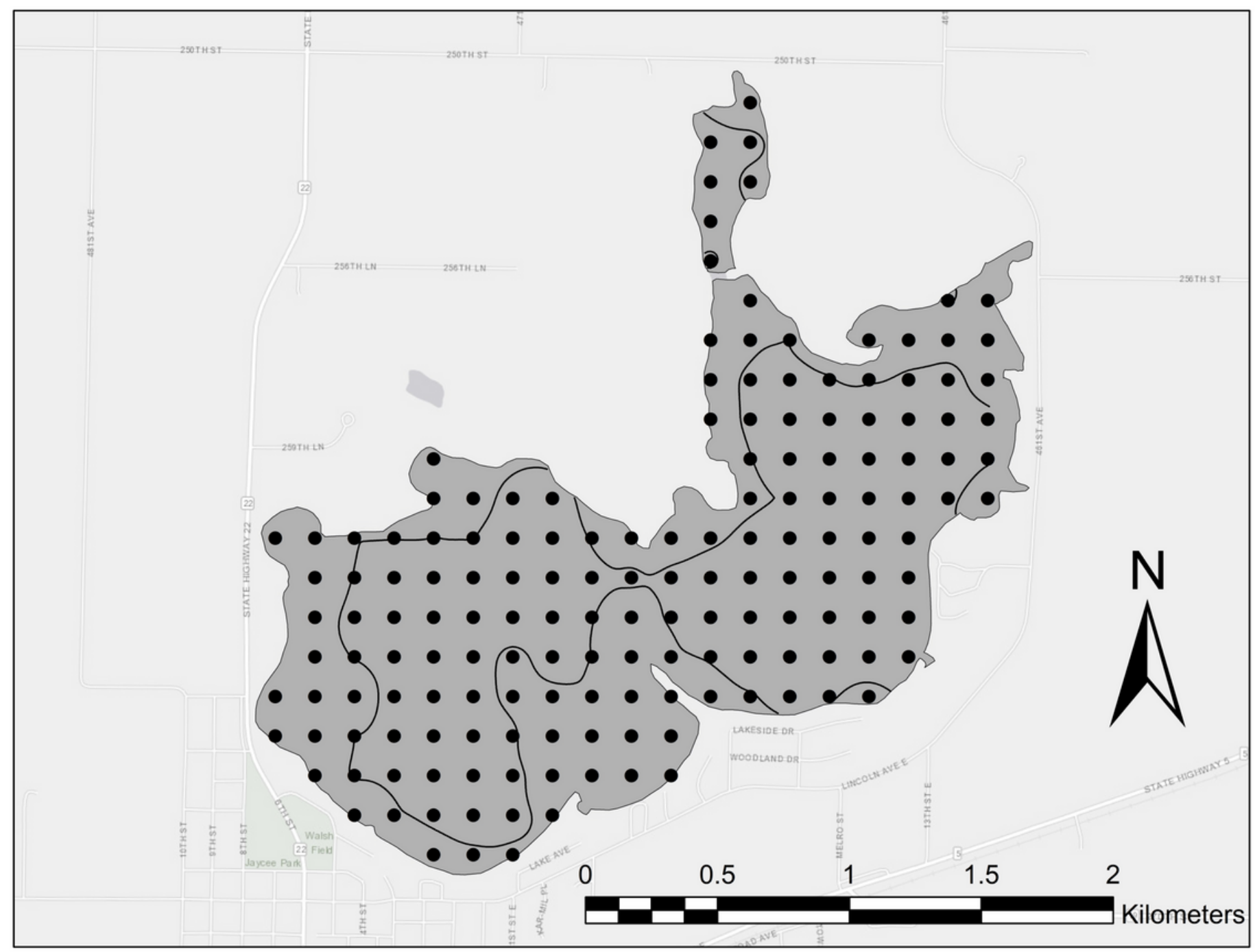

Figure 3

Grid of survey points in Titlow Lake for surveys during the 2019 growing season in Sibley Co., MN. Contour lines represent changes of depth by $0.5 \mathrm{~m}$ intervals. Contour lines derived from depth data at sample points $(n=163)$. 


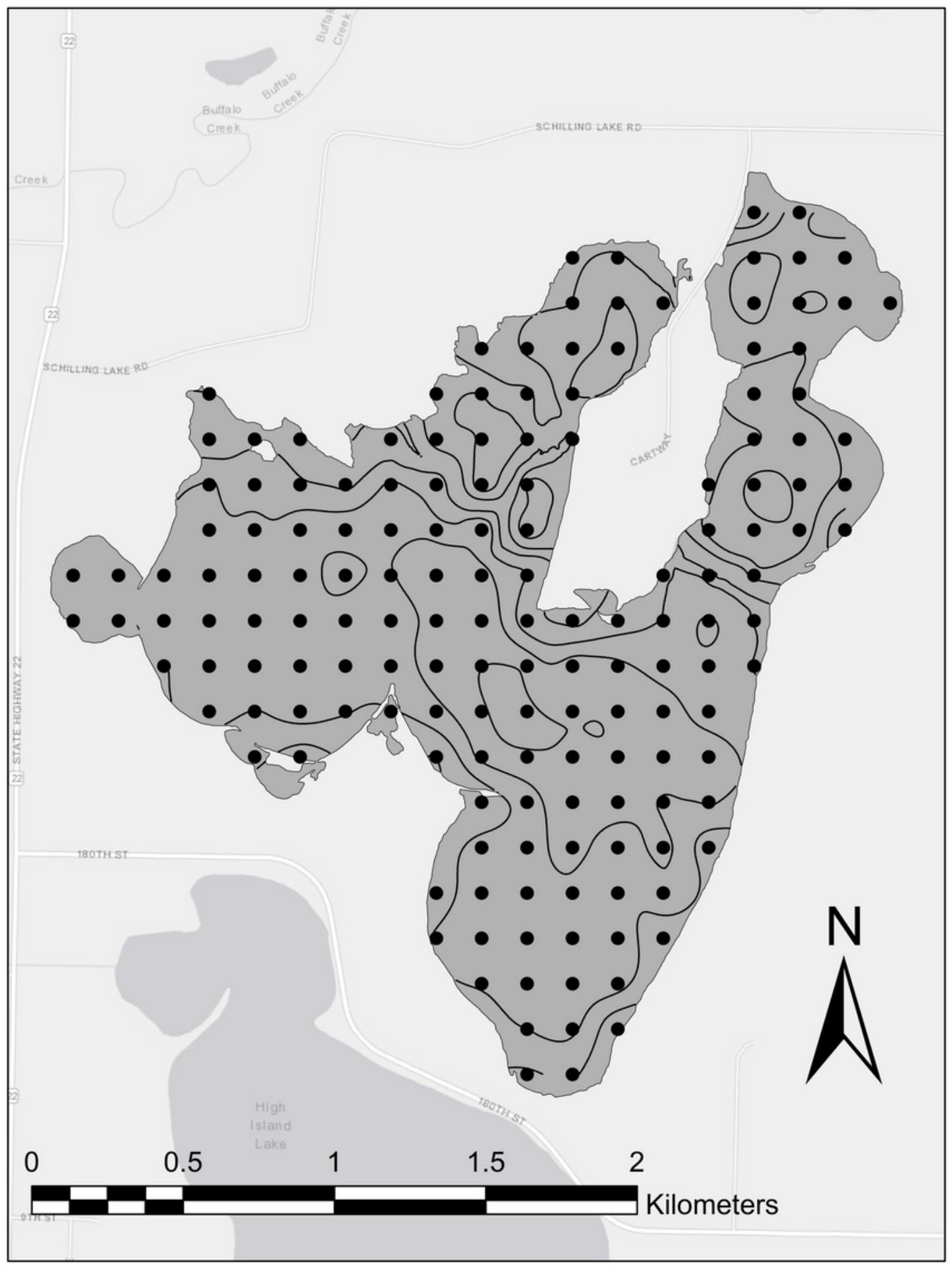

Figure 4

Grid of survey points in Schilling Lake for surveys during the 2019 growing season in Sibley Co., MN. Contour lines represent changes of depth by $0.5 \mathrm{~m}$ intervals. Contour lines derived from depth data at sample points $(n=160)$. 


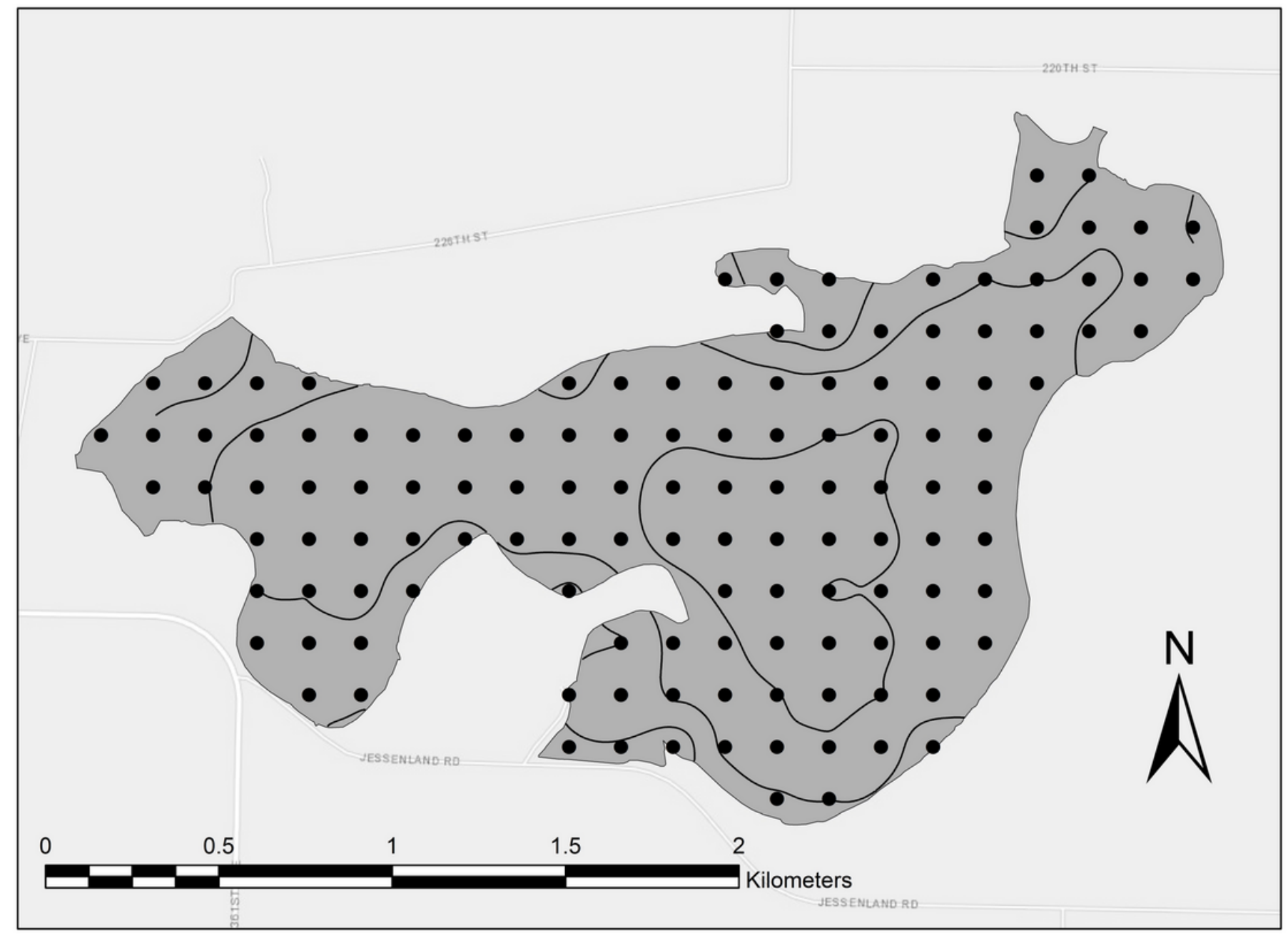

Figure 5

Grid of survey points in Silver Lake for surveys during the 2019 growing season in Sibley Co., MN. Contour lines represent changes of depth by $0.5 \mathrm{~m}$ intervals. Contour lines derived from depth data at sample points $(n=129)$. 


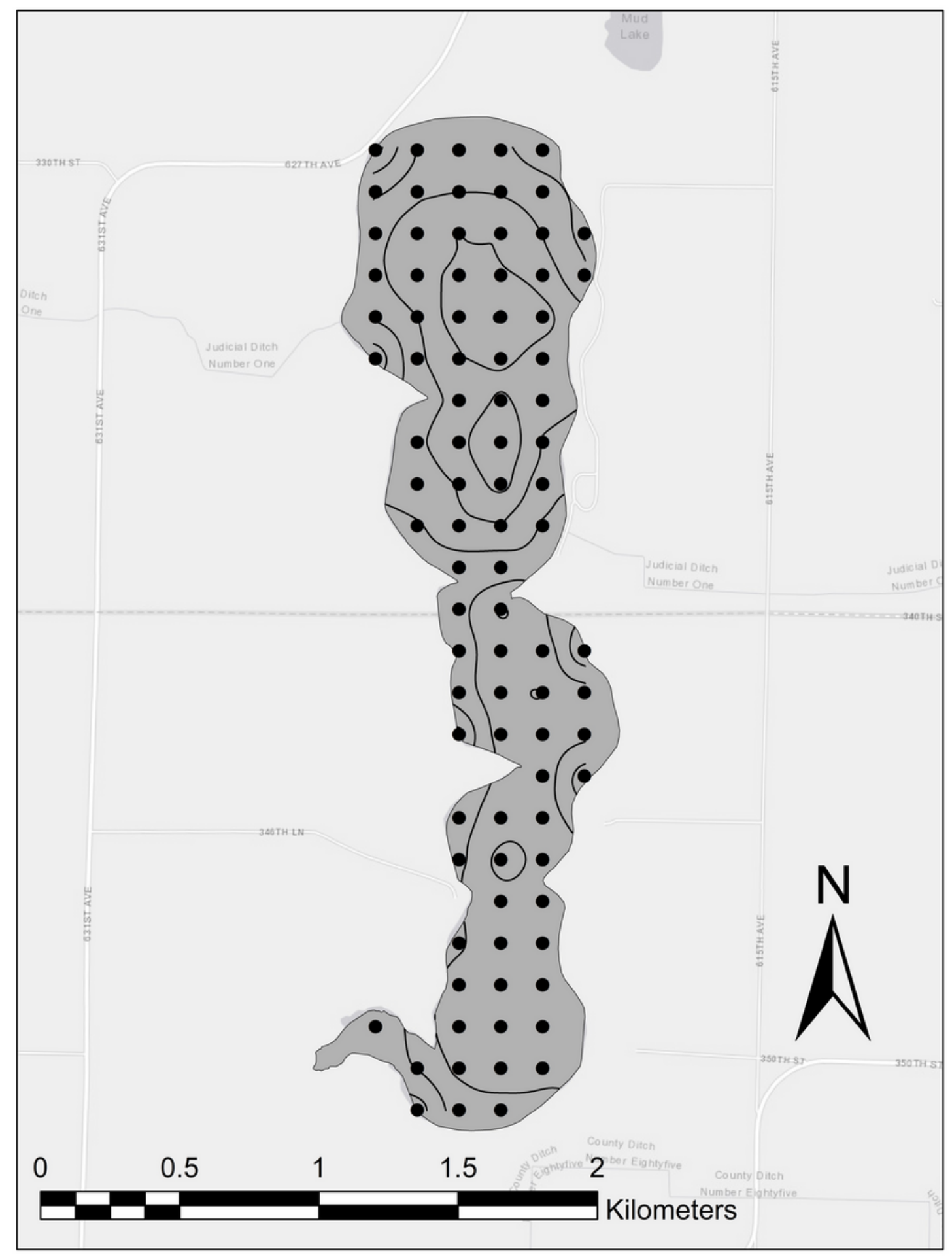

Figure 6

Grid of survey points in Clear Lake for surveys during the 2019 growing season in Sibley Co., MN. Contour lines represent changes of depth by $0.5 \mathrm{~m}$ intervals. Contour lines derived from depth data at sample points $(n=90)$. 